\title{
Outsourcing and Competition Policy
}

\author{
Cosimo Beverelli \\ Graduate Institute of International Studies \\ Kornel Mahlstein \\ Graduate Institute of International Studies
}

\begin{abstract}
We analyze optimal competition policy by a Competition Agency (CA) in a model with two countries, North and South, were a final good is produced by Northern oligopolistic firms using an input that can either be produced within the firm (vertical integration) or outsourced to Southern oligopolistic producers with lower labor costs (outsourcing). In the case where the final good is only consumed in the North and there is free entry in the South, we find that optimal competition policy in the North is the adoption of a tougher stance. However, with a CA in the South, the Southern CA would optimally appropriate outsourcing rents through restrictions on the degree of competition among domestic firms. In this case the optimal response of the Northern CA would be inaction. In the case where the final good is consumed in both countries, we find that optimal competition policy in the South is marginally affected by the share of Southern consumption, leaving relatively important incentives to engage in rent-shifting. However, for a high enough share of Southern consumption, the interaction between the Northern and Southern CA is shown to be of the Prisoner's Dilemma type, whereby the Nash equilibrium is Pareto-suboptimal and mutual cooperation on competition policy is globally desirable
\end{abstract}

(C) The Authors.

All rights reserved. No part of this paper may be reproduced without the permission of the authors. 


\title{
Outsourcing and Competition Policy
}

\author{
Cosimo Beverelli Kornel Mahlstein
}

February 21, 2007

\begin{abstract}
We analyze optimal competition policy by a Competition Agency (CA) in a model with two countries, North and South, were a final good is produced by Northern oligopolistic firms using an input that can either be produced within the firm (vertical integration) or outsourced to Southern oligopolistic producers with lower labor costs (outsourcing). In the case where the final good is only consumed in the North and there is free entry in the South, we find that optimal competition policy in the North is the adoption of a tougher stance. However, with a CA in the South, the Southern CA would optimally appropriate outsourcing rents through restrictions on the degree of competition among domestic firms. In this casem the optimal response of the Northern CA would be inaction. In the case where the final good is consumed in both countries, we find that optimal competition policy in the South is marginally affected by the share of Southern consumption, leaving relatively important incentives to engage in rent-shifting. However, for a high enough share of Southern consumption, the interaction between the Northern and Southern CA is shown to be of the Prisoner's Dilemma type, whereby the Nash equilibrium is Pareto-suboptimal and mutual cooperation on competition policy is globally desirable.
\end{abstract}

\section{Introduction}

The objective of this paper is to analyze optimal competition policy when firms delocalize production of intermediate inputs abroad. What has been termed "global production shifting" is a complex phenomenon by which the production of goods (and increasingly also services) is spread across different firms and/or different countries. To clarify the terminology used in this paper, a few definitions are useful. Broadly speaking, a firm that uses one or more intermediate inputs in the production of a final good can decide to produce its inputs within its boundaries or to outsource its production to an independent supplier. In the former case, the firm engages in vertical integration if it produces the input domestically, and in foreign direct investment (FDI) and intra-firm trade if the input is produced abroad. In the case of outsourcing, on the other hand, the firm can either buy the input domestically (domestic outsourcing), or buy it from a 
foreign supplier, engaging in arm's length trade (foreign outsourcing). ${ }^{1}$ Foreign outsourcing is equivalent to offshoring, defined in the business literature as the movement of a business process done at a company in one country to the same or another company in another country. Given these definitions, companies subcontracting in the same country would be outsourcing, but not offshoring. A company moving an internal business unit from one country to another would be offshoring, but not outsourcing. A company subcontracting a business unit to a different company in another country would be both outsourcing and offshoring. In our model, we deal with the case of foreign outsourcing. Throughout our paper we analyze the case of "foreign outsourcing", whereby firms from one nation (that we call "North") outsource the production of intermediate inputs to firms in another nation (that we call the "South"). For simplicity, we sometimes use the compact term "outsourcing".

Over the last twenty years outsourcing has become increasingly important. Yeats [27] finds that trade in intermediates accounts for approximately 30 percent of total trade in the US. He also notices that this figure may be significantly larger for developing countries, as they have progressively become the focus of outsourcing from developed countries. Hanson et al. [15] show how foreign outsourcing by US firms has grown at paces exceeding the growth of intra-firm trade within the same firms.

As noted by Spencer [26], a common motive for international procurement of intermediate inputs either through outsourcing or through intra-firm transactions (FDI) is to reduce costs by producing in low wage countries. China is certainly a point in case. With the liberalization of trade and services and the accession of China to the WTO, many firms started to shift production of intermediate manufactured goods there. The share of processing exports (i.e., goods produced using imported inputs) in total manufacturing exports has increased from 35 percent in 1988 to 57 percent in 2003 [26].Outsourcing constitutes a big part of this. The phenomenon is especially marked in the electronic and computer industry, where the components are produced in China and Taiwan and then assembled in Ireland for instance.

As economic integration has processed, policy makers and scholars have recognized the possible links between trade and competition policy. In particular, as argued by Horn and Levinsohn [21], they have "started to ponder the possible conflicts arising from nationally pursued competition policies in a more unified goods market".

Our study contributes to this ongoing debate, analyzing the theoretical links between outsourcing and competition policy through a simple model with two countries, North and South. Our starting point is the observation that outsourcing is related to cost savings. In a less than perfectly competitive market, thus, outsourcing will be associated with rents, which can be shifted through an active competition policy. We thus assume throughout the paper an oligopolistic market structure, where firms engage in quantity competition, and a Competition

\footnotetext{
${ }^{1}$ This is the common classification done by trade economists, see for example Antràs and Helpman [2].
} 
Agency (CA) in the North that optimally sets the number of firms by maximizing domestic welfare. Concerning the South, we consider the two different scenarios of no Competition Agency and presence of Competition Agency, with a similar institutional role as its Northern homologue.

The paper is broadly divided in two parts. The first analyzes the case where the final good - which is just a relabeling of the intermediate input - is only consumed in the North. This could be thought of as the initial stage of a development process whereby Southern consumers progressively acquire purchasing power as the country develops. The second part deals with a scenario where consumers are more evenly distributed geographically - which can be thought of as a more advance stage of development.

In the first part, we start with an initial equilibrium were, due to prohibitive trade costs, the industry structure is one of vertical integration, so that each firm in the North produces both the input and the final good. If, as a result of trade liberalization, outsourcing becomes viable, we show that optimal competition policy in the North dictates the adoption of a tougher stance if there is free entry in the South, or inaction if there is a Competition Policy in the South. The reason is that the Southern CA will entirely appropriate outsourcing rents, leaving Northern firms indifferent between outsourcing and vertical integration and leaving the problem of the Northern CA unchanged. We thus show that competition policy can entirely substitute for trade policy as a rent-shifting device. However, rent-shifting is not Pareto efficient. From a global welfare perspective, free entry in the South would be optimal (we assume no fixed costs for Southern firms). Since the Southern CA has no interest in consumer protection, from an institutional perspective the optimal outcome can only be achieved if we allow for monetary transfers from the North to the South.

The second part deals with the scenario in which the final good is consumed in both countries. With an increasing number of Southern consumers, the protection of the consumer surplus becomes more attractive for the Southern CA. If the share of Southern consumers in world consumption is high enough, the interaction between Competition Agencies assumes the traits of a standard Prisoner's Dilemma: both would prefer mutual cooperation (defined as free entry in the absence of fixed costs) to mutual defection (defined as the optimal unilateral setting of competition policy), but there is a unilateral incentive to defect that leads to a Pareto-inefficeint Nash equilibrium. From an institutional perspective, the optimal outcome can be achieved through an agreement between Competition Agencies that makes mutual cooperation more attractive than unilateral defection.

The main message of our paper is that if globalization leads to higher growth rates of consumption in the South than in the North, the incentives to use competition policy as a mean to shift rents in a beggar-thy-neighbor fashion may actually shrink, and the establishment of mutual agreements on the conduct of competition policy may become more attractive. 


\section{Literature review}

The issue of how firms organize their production on a global scale has recently received new attention in Economics, particularly in International Trade. A growing body of literature has looked at the organizational choices of individual firms using relatively new theories of the firm from industrial organization. The resulting literature has been labeled "new new trade theory". The first strand of this "new new trade theory", popularized by Melitz [23], looks at firm-level differences in productivity, and their effects on trade and investment decisions (Helpman, Melitz and Yeaple [18]). Concerning the decision of business firms, it mostly focuses on the choice of which markets to enter, which depends on size and productivity of firms. The second branch of new new trade theory, based on the property rights approach to the theory of the firm introduced by Grossman and Hart [11] and Hart and Moore [20], analyzes organizational decisions of business firms, to explain the causes and conditions underlying across-boundaries fragmentation of production. Most of the literature in the second branch of "new new" trade theory uses the Grossman-Hart-Moore approach to explain the "make or buy" decision, that is, the decision to produce intermediate inputs within the boundary of a vertically integrated firm or to contract out the supply of inputs to an external specialized producer.

A common denominator of these models is the use of Dixit-Stiglitz monopolistic competition framework among final good producers. They assume a potentially large number of varieties to be produced, and monopoly over the production of each of them. ${ }^{2}$ In such a framework, there is not much role for competition policy: the best a Competition Agency can do is to leave the number of firms to be determined by free entry.

There is also a rich international trade literature on the issue of rentextraction under imperfect competition. This literature is based on the simple consideration that when markets are less than perfectly competitive, there are rents that can be extracted. The focus has been on trade policy as the instrument to shift and appropriate rents. A standard result in this literature is that the imposition of a tariff (import subsidy) is the optimal rent-extraction policy vis-à-vis a foreign monopolist or oligopolist facing linear (CES) demand (Brander Spencer [6]). When market power is on both domestic and foreign market, the appropriate policy instrument to shift rents from the foreign to the home country is an export subsidy (under Cournot competition between a domestic and a foreign firm) or an export tax (under Bertrand competition) (Brander and Spencer [7], Eaton and Grossman [9]).

A major contention of our paper is that competition policy can be used as a rent-extraction tool. Competition policy, we argue, can entirely substitute for trade policy as a rent-shifting instruments for the South. This result is linked to the oft-made argument that international trade liberalization, by limiting the possibility of beggar-thy-neighbor trade policy, induces countries to instead use

\footnotetext{
${ }^{2} \mathrm{~A}$ recent contribution by Bernard, Redding and Schott ([4]) introduces multi-product firms in a Melitz-type model to distinguish between extensive and intensive margin effects of trade liberalization.
} 
beggar-thy-neighbor competition policy.

Horn and Levinsohn [21] investigate the link between merger policy (defined as the choice of the optimal level of industry concentration) and trade liberalization in a partial-equilibrim, two-countries model. They find no clear-cut relationship between international trade liberalization an merger policy. In other words, they do not establish whether the two are complement or substitutes. On the other hand, we find that, with a Competition Authority in the South, outsourcing is systematically coupled with rent extraction, with the degree of rent extraction depending on the geographical distribution of consumers and marginal cost savings. This is due to the fact that we present different aspects of globalization: for Horn and Levinsohn, trade liberalization brings two-way trade in identical product. In our model, it brings trade of intermediates in one direction and of final goods in the other.

It is useful to point out that we do not make a case for anti-competitive practices for developing countries, except in the polar case of no consumption of the final good in the South. On the contrary, under the more reasonable assumption that consumers are distributed in both countries, we show that those practices are sub-optimal from a global perspective. However, we also show that in a decentralized (Nash) setting of competition policy, there exists incentives to use competition policy as a mean to appropriate outsourcing rents. This points to the issue of whether competition policy, and in particular the adoption of restrictive practices, can sustain development. ${ }^{3}$

Some scholars have argued that lax enforcement of competition policy is second-best instrument to increase investments (higher prices leading to more funds to be invested by the firm), the first-best being direct policy instruments such as subsidies. There is a debate as to whether lax competition policy helped spurring development in East Asia. Porter et al. (cited in [10]), for example, find that efforts to restrict competition through cartels were rarely found in successful industries but were far more prevalent in unsuccessful ones.

Our work is also related to the issue of institutional multilateralization of competition policy, which has attracted quite some attention in policy circles. This issue was also on the agenda of the World Trade Organization (WTO), with the EU advancing the proposal for a Global Agreement on Competition (MAC). However, it was dropped from the Work Programmes of the Doha Round, thanks to the opposition of most developing countries - on the basis of their unwillingness to surrender the "policy space" for implementing industrial policies discriminating in favor of domestic firms and promoting national champions - and the ambivalence of the US. ${ }^{4}$ Proponents of a global MAC have argued that such an agreement could be mutually beneficial to developed and developing countries. To the former, mostly because of market access; to the latter - some authors have argued - for the following reasons: a) An MAC effectively dealing with international export cartels would help developing countries getting cheaper inputs; ${ }^{5}$ b) an MAC could limit the abuse of anti-dumping prac-

\footnotetext{
${ }^{3}$ The following paragraph draws on Evenett et al [10].

${ }^{4}$ See Bhattacharjea [5].

${ }^{5}$ The view that private international cartels effectively distort international trade has been
} 
tices by developed countries by establishing more severe principles under which alledgedly predatory pricing is punishable; c) curbing the abuse of Intellectual Property Rights (IPRs) as effective cartel-types arrangements without an actual cartel agreement. ${ }^{6}$

Clearly, a major contention of this literature is that the most harmful anticompetitive practices are by developed countries' firms through cartelization. ${ }^{7}$ In our paper we clearly distinguish between the two cases of free entry (aka perfect competition) and restriction of competition (via a Competition Authority) on the input market. The latter case, we believe, has not received significant attention in the cited literature. At the same time we would like to emphasize our normative case for cooperation in competition policy - under some conditions on the geographical distribution of final good consumption.

After this review of the related literature, we now present a theoretical model that analyzes the links between competition policy and outsourcing. Since the geographical distribution of final good consumers is the key variable affecting our results, we first analyze the case in which all consumption is in the North - firstly by assuming free entry in the South, then by assuming optimal setting of the number of Southern firms. We then consider the model with consumers in both countries, and analyze the interaction between firms and Competition Authorities.

\section{The model with consumers only in the North}

Consider a simple setting with consumers maximizing the following quasi-linear utility function:

$$
U(q, I)=\alpha \sum_{i=1}^{v} q_{i}-\frac{1}{2} \beta\left[\sum_{i=1}^{v} q_{i}^{2}+2 \sum_{i \neq j} q_{i} q_{j}\right]+I
$$

where $q_{i}$ is the output of an homogenous consumption good by firm $i$, and $M$ represents the aggregate measure of all the other goods is the economy, treated as numeraire. Straightforward utility maximitazion yields linear demand of the form:

$$
p_{i}=\alpha-\beta Q
$$

advanced by Levenstein and Suslow [22], who show that the forty-odd international cartels that had been prosecuted in the US and the EU operated in various regions of the world, lasted several years and affected a wide range of products. Whether an MAC would effectively help dealing with international cartels, however, is disputable. Evenett et al. [10], for example, emphasize the enormous asymmetries of interests and capabilities between developed and devolping countries involved. Moreover, for an MAC to be effective in dealing with international cartels, it would require international jurisdiction.

${ }^{6}$ Bhattacharjea [5].

${ }^{7}$ Evenett et al [10] further notice that in economies which are recipeints of FDI, there is the issue of restrining multinationals from establishing dominant positions wy driving out of the market (or by acquiring) small, local firms which cannot compete with large productive foreign firms. A case in point cited by the authors is Argentina, where merger control was introduced precisely for this reason in 1999 . 
where

$$
Q=\sum_{i=1}^{v} q_{i}
$$

Without loss of generality, we set $\beta=1$. We assume that the homogenous consumption good is produced by symmetric firms engaging in Cournot (quantity) competition. A typical producer $i$ hires low skilled labor (L) and high skilled labor $(\mathrm{H})$ to produce the final good, with a cost structure that comprises both variable and fixed costs:

$$
T C_{i}=w a_{L} q_{i}+r a_{H} f
$$

where $w$ is the reward to unskilled labor, $a_{L}$ is the unit unskilled labor requirement (an inverse measure of the productivity of L workers), $q_{i}$ is the firm's output, $r$ is the (exogenous) reward to unskilled labor, $a_{H}$ its unit requirement and $f$ is a measure of fixed costs. We assume that unskilled labor is only used in the variable component of the cost function, and skilled labor is only used in the fixed cost component. We think of fixed costs as costs related to start-up, research and development, marketing, logistics and all other activities that can only be performed by high skilled workers. Variable costs, on the other hand, are the costs related to the physical production of the final good.

Production of the final good requires an intermediate input, which can either be produced within the firm (case of vertical integration) or outsourced to a specialized producer. The technology for the final good production is simple: in order to produce one unit of final good, one unit of the input is needed. In other words, the final good is simply a relabeling of the intermediate. ${ }^{8}$

Specialized intermediate producers use only unskilled labor, with a unit labor requirement equal to $a_{L}$. Crucially. we assume that specialized intermediate producers are only located abroad (the "South"), and have exogenously lower marginal costs of production. ${ }^{9} \mathrm{We}$ justify this assumption as follows: assume $a_{L}=a_{L}^{*}$, where $a_{L}^{*}$ is the unit labor requirement in the production of the intermediate good in the South. ${ }^{10}$ Next, let perfect competition and free trade in the numeraire: if $a_{I}$ is the unit labor requirement at home (the "North") $a_{I}^{*}$ in the South - and $w$ is the reward to labor in the North - $w^{*}$ in the South - marginal cost pricing respectively yields $w=\frac{1}{a_{I}}$ and $w^{*}=\frac{1}{a_{I}^{*}}$. In words, the wage is pinned down by the productivity in the outside sector. By free trade in the numeraire, the law of one price applies: $p_{M}=p_{M}^{*}=1$. Then the following relation holds: $w^{*}<w$ if, and only if, $a_{I}^{*}>a_{I}$. Lower marginal costs of production of the intermediate good in the South are insured by letting $a_{L}=a_{L}^{*}$ and $a_{I}^{*}>a_{I}$. In words, by assuming that the North and the South are equally efficient in the production of intermediate goods, but the North is

\footnotetext{
${ }^{8}$ For a similar assumption, see for example Grossman and Helpman [13].

${ }^{9}$ The same assumption is made by Shy and Stenbacka [25], who however consider the multiple-input case. In their paper, too, there is Cournot competition among final good producers - introduced to study the effect of increased competition on the range of outsourced inputs and the strategic interactions between outsourcing firms.

${ }^{10}$ We consider the case in which the technology to produce the intermediate good is mature and standardized, so that every country has acces to it.
} 
more productive in the outside sector, so that the reward to unskilled labor and the cost of production of the input are lower in the South. Without loss of generality, we set marginal costs of Southern intermediate good producers equal to zero. For simplicity, we assume that specialized intermediate good producers do not incur any fixed costs of production. In this part of the paper, we deal with the case in which the final good is exclusively consumed in the North.

We start with an equilibrium with pervasive vertical integration. To make sure this is the initial equilibrium, we assume prohibitive trade costs, so that it is more costly to import the input than producing it within the firm. Consider then a market with $v$ symmetric vertically integrated producers competing à la Cournot. To simplify notation, let $w a_{L} \equiv \lambda$ and $r a_{H} f \equiv k$ in equation (2), so that the cost structure of each firm is equal to:

$$
T C_{V}=\lambda q_{V}+k
$$

Profit Maximization, subject to the demand function in (1) yields the following equilibrium quantity and price:

$$
\begin{aligned}
& q_{V}=\frac{\alpha-\lambda}{(1+v)} \\
& p_{V}=\frac{\alpha+v \lambda}{1+v}
\end{aligned}
$$

We get the standard results that quantity is negatively related to marginal costs and the more competitors there are the lower is the market price.

$$
\pi_{V}=\left(\frac{\alpha-\lambda}{1+v}\right)^{2}-k
$$

Industry producer surplus consists of industry profits minus fixed costs:

$$
P S(v) \equiv v\left(\pi_{V}\right)=v\left(\frac{\alpha-\lambda}{1+v}\right)^{2}-v k
$$

The linear specification for the demand function easily allows us to express the consumer surplus as follows:

$$
C S(v)=\frac{1}{2}\left(\frac{v(\alpha-\lambda)}{1+v}\right)^{2}
$$

Following Horn and Levinsohn ([21]), the reduced form welfare level in the model economy under consideration consists of consumer surplus and producer surplus (inclusive of industry fixed costs):

$$
\begin{aligned}
W_{V} & \equiv C S(v)+P S(v) \\
& =\frac{1}{2}\left(\frac{v(\alpha-\lambda)}{1+v}\right)^{2}+v\left(\frac{\alpha-\lambda}{1+v}\right)^{2}-v k
\end{aligned}
$$

Notice that in the case of free entry operating profits of firms would just cover the fixed costs and the producer surplus would be zero. Depending on the task of the Competition Authority, whether its duty is to maximize the consumer surplus or total welfare, the optimal number of firms may differ. 


\subsection{Competition policy under vertical integration}

We now introduce a Competition Authority (CA), whose mandate is to maximize national welfare by choosing the optimal number of firms. In a situation in which firms are vertically integrated, the CA sets $\left(W_{V}\right)_{v}=0$. The optimal number of firms is:

$$
v^{*}=\left[\frac{(\alpha-\lambda)^{2}}{k}\right]^{\frac{1}{3}}-1
$$

The optimal number of firms is negatively related to the size of the fixed costs and positively to its marginal costs. For this to be an equilibrium, we impose the condition $\pi_{V I}\left(v^{*}\right) \geq 0$, which translates into the following lower bound on fixed costs: $k \leq(\alpha-\lambda)^{\frac{2}{3}}$.

\subsubsection{Comparison with Free Entry equilibrium}

In a free entry equilibrium, each producer makes zero pure profits: $\pi_{V I}=0$. The number of firms in such an equilibrium would then be:

$$
v^{F E}=\left[\frac{(\alpha-\lambda)^{2}}{k}\right]^{\frac{1}{2}}-1
$$

The optimal number of firms set by a CA is lower than under free entry, reflecting the trade off between fixed costs savings and lower consumer surplus due to less competition.

\section{Outsourcing}

We now want to study how competition policy should optimally react to an industry change in business operations. The easiest scenario to consider is one in which, due to an exogenous reduction in trade costs, outsourcing becomes viable. Importantly, we assume no contracting costs between Northern and Southern firms, as well as no search costs. Furthermore, we assume that skilled labor is prohibitively expensive in the South, so that it is not viable to shift the entire production of the final good there (recall that high skilled labor is needed to cover fixed costs). These assumptions, together with symmetry across firms within the same nation, imply that there will be a shift to pervasive foreign outsourcing: the intermediate good will be produced in the South, at lower marginal cost, while the assembling will be conducted in the North. For simplicity, we let fixed costs for final good producers be the same under outsourcing and under vertical integration. This assumption is easily justified by noting that fixed costs exclude the costs of physical production, as explained above.

We denote by $m$ the number of intermediate good producers in the South. They engage in Cournot competition among them. On the other hand, we denote by $n$ be the number of final good producers engaging in outsourcing. In a situation in which the number of firms does not change, $n$ is equal to 
$v$. However, if the CA optimally sets the number of domestic firms taking into account their cost structure (see equation (5)), $n$ will generally be different from $v$.

\subsection{Free entry in the South}

Consider first the simple case of free entry in the South. In the absence of fixed costs, the price of the intermediate good is equal to its marginal costs $c$, set equal to zero. With no final good consumption and zero producer surplus in the South, we can thus limit our analysis to the Northern market only.

As before, Norther firms compete à la Cournot, facing linear demand and producing homogenous goods. The cost structure for the $j$ 'th Northern firm that outsources the production of the input to the South is equal to:

$$
\begin{aligned}
T C_{j} & =w^{*} a_{L}^{*} x+r a_{H} f \\
& =w^{*} a_{L} x+k \\
& =c x+k
\end{aligned}
$$

where $x$ is the quantity of the intermediate good bought from Southern firms. Using the simple relabling technology described above, we have that the output of a Northern firm, $q$, is equal to $x$; furthermore, since we let $c=0$, we have $T C=k$. Profit maximization under the linear demand in (1) then yields:

$$
\begin{aligned}
& q_{n}=p_{n}=\frac{\alpha}{1+n} \\
& \pi_{n}=\left(\frac{\alpha}{1+n}\right)^{2}-k
\end{aligned}
$$

\subsubsection{Optimal competition policy}

Let's compute the unconstrained optimal (from the point of view of a CA maximizing domestic welfare) number of firms and then check whether this equilibrium is implementable. The relevant welfare function is:

$$
\begin{aligned}
W_{O} & \equiv C S(n)+P S(n) \\
& =\frac{1}{2}\left(\frac{n \alpha}{1+n}\right)^{2}+n\left(\frac{\alpha}{1+n}\right)^{2}-n k
\end{aligned}
$$

The optimal $n$ is then equal to:

$$
n^{*}=\left(\frac{\alpha^{2}}{k}\right)^{\frac{1}{3}}-1
$$

Under the assumption that $k_{O}<k_{V}$, one can easily check that $n^{*}$ is higher than $v^{*}$. However, we have to make sure that firms will make more profits than under vertical integration, so that outsourcing is also optimal for Northern firms (participation constraint). We thus equate profits for the $n$ and $v$ types, and 
check that profits are not lower than before. Equating (3) to (6) and solving for $n$, we can find the maximum number of final good producers such that each of them makes the same profits as under vertical integration (we call it $\bar{n}$ ):

$$
\begin{aligned}
\bar{n} & =\frac{a v-\lambda}{a-\lambda} \\
& =\frac{\alpha}{\sqrt[3]{k(\alpha-\lambda)}}-1
\end{aligned}
$$

where we have used $v^{*}$ for the number of vertically integrated producers. This puts an upper limit on the number of final goods producers in the North. In order for $n^{*}$ to be implementable, it must be smaller than $\bar{n}$. The difference between the optimal number of firms under outsourcing and $\bar{n}$ is equal to:

$$
\begin{aligned}
n^{*}-\bar{n} & =\sqrt[3]{\left(\frac{\alpha^{2}}{k}\right)}-\frac{\alpha}{\sqrt[3]{k(\alpha-\lambda)}} \\
& =\sqrt[3]{\left(\frac{\alpha^{2}}{k}\right)}\left[1-\sqrt[3]{\left(\frac{\alpha}{\alpha-\lambda}\right)}\right]
\end{aligned}
$$

It is easy to show that this difference is always negative, since $\alpha>\lambda$. In words, the optimal number of firms under outsourcing in always less than the maximum number of firms that a market with outsourcing can sustain. From the point of view of the CA, this means that this constraint is not binding, and it can impose the optimal number of firms in an outsourcing equilibrium, given in (6). Having established this result, we can compare $n^{*}$ and $v^{*}$ to see that:

Observation 1 With free entry in the South and consumers only in the North, the optimal number of Northern firms under outsourcing, $n^{*}$, is unambiguously higher than the optimal number of firms under vertical integration, $v^{*}$. A CA seeking to maximize national welfare should adopt a tougher competition policy stance following a switch to an outsourcing mode.

The intuition is that under outsourcing final good producers can produce at lower marginal costs so their ex ante expected profits are higher. Hence, entry is more profitable than before; since fixed costs are unchanged, the market can support a higher number of firms.

\section{$5 \quad$ Welfare under an inactive CA}

Consider now the counterfactual scenario of a passive Competition Authority that does not react to an industry switch to an outsourcing mode. Is inaction costly? We establish that inaction leads to a welfare loss which is higher, the more relevant marginal cost savings from outsourcing and the lower the price elasticity of demand. 
In the case in which the $\mathrm{CA}$ does not re-optimize and keeps the number of firms equal to $v^{*}$, the outsourcing equilibrium takes the following form:

$$
\begin{gathered}
q_{V, \text { OUT }}=\frac{\alpha}{\left(1+v^{*}\right)} \\
p_{V, \text { OUT }}=\alpha-\frac{\left(v^{*}\right) \alpha}{1+v^{*}} \\
\pi_{V, \text { OUT }}=\frac{\alpha^{2}}{\left(1+v^{*}\right)^{2}}-k
\end{gathered}
$$

The non-reoptimized welfare level is:

$$
\begin{aligned}
W_{V, \text { OUT }} & \equiv C S(v, 0)+P S(v, 0) \\
& =\frac{1}{2}\left(\frac{\left(v^{*}\right) \alpha}{1+v^{*}}\right)^{2}+v^{*}\left(\frac{\alpha}{1+v^{*}}\right)^{2}-\left(v^{*}\right) k
\end{aligned}
$$

where 0 is the effective marginal cost of the input paid by final good producers when they outsource. If the CA re-optimizes, on the other hand, welfare is given by equation (7), where $n$ is the optimal number of final good producers as in equation (8). Plugging equation (5) into (11) and equation (8) into (7), we can compute the mistake done by the $\mathrm{CA}$ when it ignores the shift to outsourcing (plotted in Figure 1): ${ }^{11}$

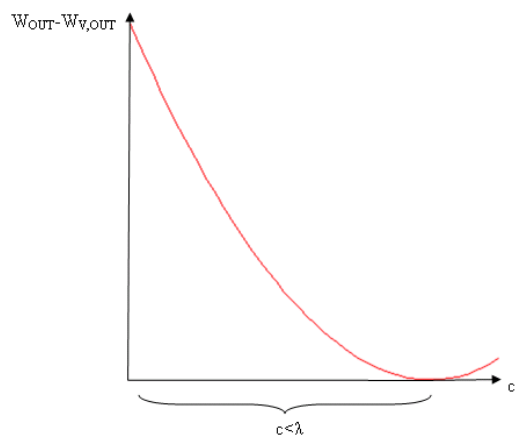

Figure 1. Welfare costs of myopic CA

As one can see, the welfare cost of non reoptimizing is higher the more important are marginal cost reductions associated with outsourcing. It is also possible to show that this cost is decreasing in the price elasticity $\beta$. Intuitively, the higher the elasticity of the demand, the more the outsourcing firm will be forced to pass on the cost saving to consumers. Therefore, the policy implication is that in a very elastic market it may not be very costly not to reoptimize. We summarize this result in the next observation:

\footnotetext{
${ }^{11}$ Notice that Figure 1 is drawn ignoring the normalization $\beta=1$ and for a positive level of marginal costs associated to outsourcing $(c>0)$. As previously noted in the text, the normalizations of $\beta$ and $c$ are without loss of generality.
} 
Observation 2 A CA seeking to maximize national welfare should be more reactive to an industry shift to outsourcing the more relevant marginal cost savings and the lower the price elasticity of demand.

\subsection{Competition Authority in the South}

In the previous section we analyzed the optimal competition policy in the North, while assuming the number of Southern firms to be determined by free entry. Now, we consider the case of a Competition Authority in the South, whose mandate is the same as its Northern homologue, i.e., setting the optimal number of firms that maximizes domestic welfare.

As we will see, the Southern CA has an interest to limit competition among intermediate producers, in order to appropriate outsourcing rents. This result, however, crucially depends on the geographical distribution of consumers. With no final good consumption in the South, it is optimal for the Southern CA to engage in beggar-thy-neighbor behavior, so as to fully shift outsourcing rents to Southern firms.

We consider a two-stages game, in which each stage is a strategic interaction in itself. In the first stage there is strategic interaction between the Northern and the Southern Competition Authority. In the second stage, there is interaction between final good producers in the North and suppliers in the South. To keep the model tractable, we model their interaction as a two-stage game of perfect information. To find the subgame perfect equilibrium, we use backward induction, both for the overall game and for the game played between $m$-types and $n$-types.

Consider first the game played between $m$-types and $n$-types. In the first stage, intermediate good producers maximize profits taking into account the demand of final good producers; in the second stage, final good producers maximize profits taking into account the (linear) market demand $p=\alpha-Q$, where $Q=\sum_{i=1}^{n} q_{i}$. The $i$ 'th final good producer facing fixed costs equal to $k$ and input price $p_{m}$ will then:

$$
\begin{array}{ll}
\max _{q_{s}} & \pi_{n}=p_{n}(Q) q_{n}-p_{m} q_{n}-k \\
\text { s.t. } & \left\{\begin{array}{l}
p_{n}=\alpha-Q \\
Q=\sum_{i=1}^{n} q_{i}
\end{array}\right.
\end{array}
$$

The solution to this problem yields the final good producer's demand for intermediate, $q_{n}\left(p_{m}\right)$ :

$$
q_{n}\left(p_{m}\right)=\frac{\alpha-p_{m}}{1+n}
$$

Aggregating over all the $n$-types, and using the market clearing condition $n q_{n}=$ 
$m q_{m}$, we get:

$$
\begin{aligned}
n q n & =n \frac{\alpha-p_{m}}{1+n}=m q_{m} \equiv \sum_{i=1}^{m} q_{i} \\
& \Leftrightarrow \quad p_{m}=\alpha-\frac{1+n}{n} \sum_{i=1}^{m} q_{i}
\end{aligned}
$$

At stage one, an intermediate good producer with cost structure $T C_{m}=c q_{m}$, facing an inverse demand given by (13) will then solve the following maximization problem:

$$
\begin{aligned}
& \max _{q_{m}} \quad \pi_{m}=\left(p_{m}-c\right) q_{m} \\
& \text { s.t. } \quad\left\{\begin{array}{c}
p_{m}=\alpha-\frac{1+n}{n} \sum_{i=1}^{m} q_{i} \\
\pi_{v} \leq \pi_{n}
\end{array}\right.
\end{aligned}
$$

The second constraint is imposed because the Southern producer cannot charge a price higher than the marginal costs of the vertical integrated firm in the North, otherwise there would be no outsourcing. If this participation constrained is fulfilled - and using $c=0$ ) the solution to this problem yields:

$$
\begin{aligned}
q_{m} & =\frac{n \alpha}{(1+n)(1+m)} \\
q_{n} & =\frac{m \alpha}{(1+n)(1+m)} \\
p_{m} & =\alpha-\frac{m \alpha}{1+m} \\
p_{n} & =\alpha-\frac{n m \alpha}{(1+n)(1+m)}
\end{aligned}
$$

with associated profits equal to:

$$
\begin{aligned}
\pi_{m} & =\frac{n}{1+n}\left[\frac{\alpha}{1+m}\right]^{2} \\
\pi_{n} & =\left[\frac{m \alpha}{(1+n)(1+m)}\right]^{2}-k
\end{aligned}
$$

Consider now the interaction between the Northern and the Southern CA. If all consumers are in the North - as we have assumed so far - the Southern CA has no interest in adopting a tougher competition policy stance towards its intermediate goods producers, since this would only influence negatively domestic welfare. In this case the constraint $\pi_{v} \leq \pi_{n}$ is binding with equality, and there is no meaningful interaction between Competition Authorities. In fact, the Southern CA will make sure that outsourcing rents are fully appropriated by the South, by setting the number of domestic firms compatible such that Northern firms are just equally well off as before outsourcing. The maximum 
number of intermediate good producers such that price they charge is equal to $\lambda$ can easily be computed from equation (14), and it is equal to:

$$
\bar{m}=\frac{\alpha-\lambda}{\lambda}
$$

Since there is no final good consumption, the Southern CA will either set $m=$ $\bar{m}$. We represent the participation constraint for Northern firms in Figure 2 (drawn for a particular parametric configuration):

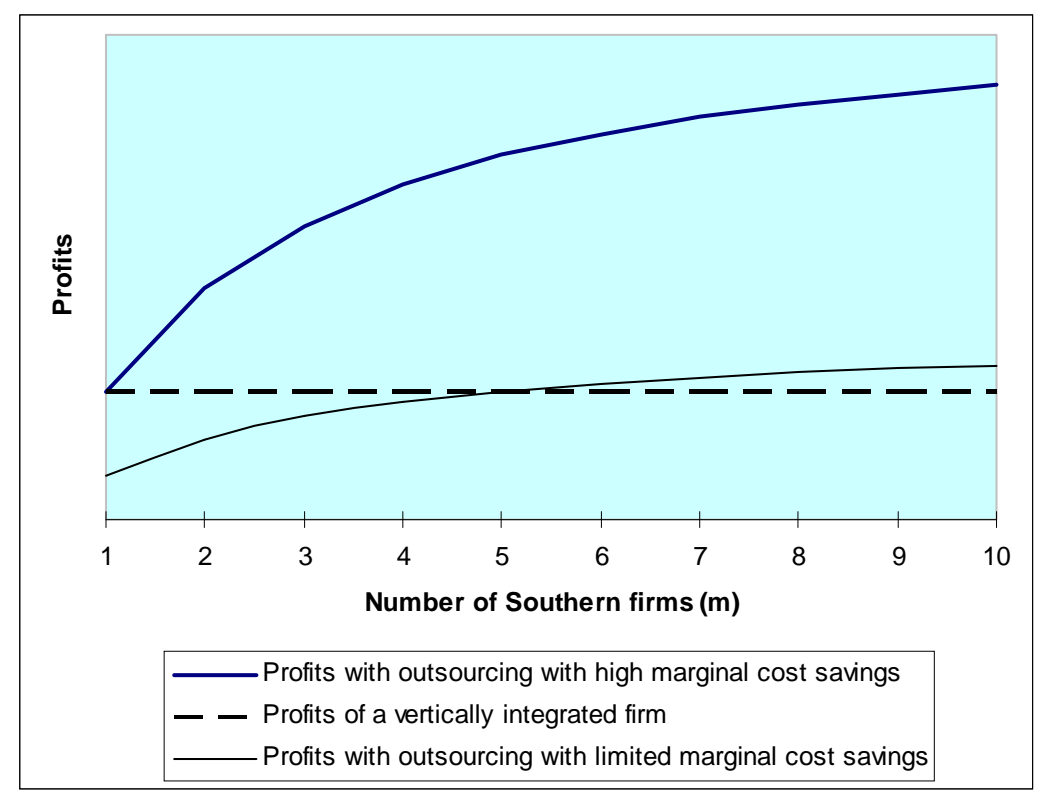

Figure 2. Profits under vertical integration and outsourcing

In the Figure, $\bar{m}$ is determined at the intersection between the profit line of vertical integration and the profit line of outsourcing. Notice that profits for the Northern firms are increasing w.r.t. the situationof vertical integration only for $m$ higher than $\bar{m}$, which is not the case here because the Southern CA has an incentive to extract all outsourcing rents. It is however possible to restrict the number of intermediate goods producers below $\bar{m}$, this does however not bring any further improvement in terms of the maximum amount of rents that can be shifted to the South, given that any higher price for the intermediate good would violate the PC of Northern firms.

Interestingly, the Northern CA's best policy changes in this case with respect to the case of free entry in the South analyzed above: it would not have to adopt a tougher stance following outsourcing, since Northern firms do not experience any marginal cost saving anymore. The results in terms of number of firms and welfare are thus identical to the one obtained above $\left(n=v^{*}, W^{N}=W^{N}\left(v^{*}\right)\right)$. We summarize these results in Observation 3 below: 
Observation 3 With a CA and no final good consumption in the South, there is room for rent shifting. The Southern CA will appropriate outsourcing rents. The response of the CA in the North to an industry shift to outsourcing is to keep the number of firms unchanged. There is no interest in adopting a tougher stance any longer.

In this case, we have seen that competition policy can entirely substitute for trade policy as a rent-extraction instrument. Notice that the extraction of outsourcing rents is implemented without any restriction on international trade.

\section{The model with consumers in both countries}

We now relax the assumption that all consumers are situated in the North. The interesting question is to analyze the incentives of the Southern CA to engage in rent-shifting activities and how the Northern homologue will react strategically to such a move from the South. To keep the model tractable, we conduct this analysis by assuming no fixed costs either in the North or in the South. ${ }^{12}$ We also assume that the final good can be exported at zero trade cost by Northern producers (so that there is free trade both on the input and the output market). Throughout the analysis, we denote $s_{N}$ the share of Northern consumption in total consumption; by normalizing world consumption to one, the share of Southern consumption is equal to $1-s_{N}$.

The geographical distribution of consumers plays a key role in determining the structure of the strategic interaction. If $s$ is high enough, i.e. almost all consumption is the North, the Northern CA's best response is to adopt a more lenient competition policy stance in order to protect its consumers. For the Southern CA, its interest is still in extracting as much rents as possible. There is no Pareto improvement over the Nash equilibrium. Or in other words, the gain to Southern consumers as a result of globally optimal competition policy of free entry is not enough to compensate the loss of Southern producer surplus. In the second case when $s_{N}$ is low enough, the Nash equilibrium is Pareto suboptimal and global free entry would be mutually beneficial. The game has the characteristics of a Prisoners' Dilemma.

As mentioned the globally optimal competition policy which maximizes global welfare would be marginal cost pricing in the North as well as in the South. In this case welfare would only consist of consumer surplus, equal to $W^{*}=\frac{\alpha^{2}}{2}$. The level of welfare corresponding to the globally optimal competition policy for each country is thus equal to:

\footnotetext{
${ }^{12}$ In Appendix A1 we show that the results obtained are not senistive to this assumption. Hence, with no fixed costs, the results are qualitatively, although not quantitatively, comparable with the ones obtained in the previous sections.
} 


$$
\begin{aligned}
W_{N}^{*} & =s_{N} \frac{\alpha^{2}}{2} \\
W_{S}^{*} & =\left(1-s_{N}\right) \frac{\alpha^{2}}{2}
\end{aligned}
$$

In a decentralized system however each CA sets the number of domestic firms taking the other CA's course of action as given. The relevant objective function for the Northern competition agency as well as for the Southern can be found below:

$$
\begin{aligned}
W^{N} & =\frac{s_{N}}{2}\left(\frac{n m \alpha}{(1+n)(1+m)}\right)^{2}+m n\left(\frac{\alpha}{(1+n)(1+m)}\right)^{2} \\
W^{S} & =\frac{\left(1-s_{N}\right)}{2}\left(\frac{n m \alpha}{(1+n)(1+m)}\right)^{2}+\frac{m n}{1+n}\left(\frac{\alpha}{1+m}\right)^{2}
\end{aligned}
$$

The respective reaction functions are defined by the following equations:

$$
\begin{aligned}
n & =\arg \max _{n} W^{N} \\
m & =\arg \max _{m} W^{S}
\end{aligned}
$$

The respective FOC's give the following reaction functions:

$$
\begin{aligned}
n & =\frac{1}{1-s_{N}} \\
m & =\frac{1+n}{1+\left(s_{N}\right) n}=2-s_{N}
\end{aligned}
$$

We get the surprisingly easy result that the number of firms uniquely depends on the geographical distribution of consumers. Inspection of (17) and (18) reveals that, in the (unconstrained) Nash setting, the Northern CA is much more sensitive than the Southern to the geographical distribution of consumers. When most of the consumers are in the North, the Northern CA optimally sets a large number of domestic firms. The Southern CA, on the other hand, optimally sets a monopoly (for high $s_{N}$ ) or a duopoly (for low $s_{N}$ ).

Defining cooperation as a policy of free entry (which, as emphasized, corresponds the globally optimal outcome) and defection as the Nash setting of the number of firms (given in (17) and (18)), we can represent the outcomes of the interaction between CA's in the following matrix:

\begin{tabular}{|l|l|l|}
\multicolumn{1}{l}{ North } & \multicolumn{1}{l}{ South } \\
\cline { 2 - 3 } Cooperation & Defection \\
\hline \multirow{2}{*}{ Defection } & $\frac{s_{N} \alpha^{2}}{4}, \frac{\left(1-s_{N}\right) \alpha^{2}}{4}$ & $\frac{s_{N} \alpha^{2}\left(2-s_{N}\right)^{2}}{2\left(3-s_{N}\right)^{2}}, \frac{\left(2-s_{N}\right) \alpha^{2}\left[4-s_{N}\left(3-s_{N}\right)\right]}{2\left(3-s_{N}\right)^{2}}$ \\
\cline { 2 - 3 } & $\frac{\alpha^{2}}{2\left(s_{N}-2\right)}, \frac{\left(1-s_{N}\right) \alpha^{2}}{2\left(2-s_{N}\right)^{2}}$ & $\frac{\left(2-s_{N}\right) \alpha^{2}}{2\left(3-s_{N}\right)^{2}}, \frac{\alpha^{2}}{2\left(3-s_{N}\right)}$ \\
\hline
\end{tabular}


What follows below is the discussion of how strategic actions depend on the distribution of consumers. When consumers are evenly distributed, a cooperative equilibrium would represent a Pareto improvement for both of them. From the perspective of the Southern CA, the move to cooperation may become problematic when the share of its consumers is to small. The objective is to find $\overline{s_{N}}$, such that the Southern CA is indifferent between the cooperative outcome and the defection/defection outcome. Note that a cooperative outcome means that the producer surplus goes to zero, in return for lower prices and a higher consumer surplus. For any level of $s_{N}$ below $\overline{s_{N}}$, the interaction between CA's has the structure of a PD. For any level of $s_{N}$ above $\overline{s_{N}}$, on the other hand, it will have the characteristics of a deadlock game.

The cut-off level of $\overline{s_{N}}$ is in most cases not uniquely specified and depends very much on the maximum level of rents that can be shifted to the South, which in turn depends upon the level of costs savings due to offshoring. If marginal cost savings are huge, it is possible to charge prices which correspond to a duopoly or a monopoly. In this case the outcome is the unconstrained maximum given above. However, such an outcome may not be feasible if it is not consistent with the participation constraint of Northern firms given that final good producers in the North have always the possibility to continue to produce the input as vertically integrated firms. They will only outsource if ex-post profits are bigger or equal to the ex -ante profits. If the South charges a price for the intermediate good which is too high and does not respect the participation constraint of Northern firms, the demand will drop to zero. If marginal cost savings are important enough, the participation constraint of Northern firm is not binding. In such a situation rent shifting is very lucrative and the share of consumers in the South must be important in order to compensate for the producer surplus loss.

The second case arises when marginal costs are less important. The price the South can charge for the intermediate goods is capped at a level such that the participation constraint of Northern firms is just binding. In this case a monopoly in the South is not able to extract monopolistic rents. Given the fact that the level of rent extraction is increasing in marginal cost saving, lower marginal costs saving require a lower share of consumption in the South in order to make them indifferent between consumer protection and rent extraction. So $\overline{s_{N}}$ lays somewhere inbetween the unconstrained $\overline{s_{N}}$ (which, as shown in Appendix A2, is equal to $2-\sqrt{2}$ ) and one, where the later corresponds to the situation in which cost savings from offshoring are just marginal.

In the constrained rent shifting case, the number of firms in the South can actually be higher than $m=2-s_{N}$. As long as the more competitive outcome of more firms in the South does not lead to a price of intermediate goods for which the participation constraint for Northern firms is not binding anymore, the rent shifted to the South do not change. The numerical results used to construct Figure 2 show that, for a given parametric configuration, any restriction on the number of firms below ten did not result in higher rents. We do assume in this case that the CA does then impose the least restrictive outcome. 
We summarize the main results of this section in the following observations:

Observation 4 If the final good is consumed both in the North and in the South, the Northern CA has an incentive to protect Northern consumers which is higher, the higher $s_{N}$. The incentives of the Southern CA to protect Souther consumers, on the other hand, only marginally depend on $s_{N}$, since the Southern CA can influence consumer surplus only indirectly.

Observation 5 If the share of Southern consumers in world consumption is high enough, the interaction between Competition Agencies assumes the traits of a standard Prisoner's Dilemma, whereby mutual cooperation is preferred to mutual defection and the Nash equilibrium is Pareto suboptimal. A mutual agreement on the conduct of competition policy between the Northern and the Southern CA would Pareto-dominate the unilateral Nash policy.

\section{Conclusions}

Foreign outsourcing of intermediate components is a salient feature of a progressively globalized world economy. The phenomenon is particularly marked by North-South flows, whereby labor-intensive components are produced in developing countries and reassembled in developed nations. In this paper, we have studied the interaction between this phenomenon and competition policy, using a simple model of oligopoly and different competition policy structures between two countries, North and South.

The first part of the paper deals with the situation in which consumers are only present in the North. The starting point is one of vertical integration and prohibitively high trade costs. The good is produced at home. As trade costs fall below a certain threshold, it becomes attractive to offshore parts of the production process.

In a setting in which competition policy is only conducted in the North, we have found that competition policy should become more restrictive under outsourcing. On the other hand, in a setting in which competition policy is conducted both in the North and in the South, outsourcing rents can be appropriated by the South, at a rate depending on the geographical distribution of consumers. In this case, the response of competition policy in the North to outsourcing is crucially determined by the optimal policy in the South, and inaction becomes optimal under full appropriation of rents. From a global competition policy point of view, the optimal one is one of marginal cost pricing in the South (no fixed costs) and one of an optimal number of firms in the North which respect the condition of equating the marginal profits of one more firm with fixed costs. From an institutional perspective, the optimal outcome can only be achieved if we allow for money transfers from the North to the South.

The second part of the paper assumes, contrary to the first one, that consumers are located both in the North and in the South. The situation becomes more complex. We assumed for simplicity that fixed costs are zero; under such 
a situation the optimal competition policy from global welfare point of view is to enforce free entry in the North as well as in the South. In a world with decentralized competition policy, the Nash equilibrium is one in which both CA's restrict competition and the outcome is globally suboptimal. As we have shown in the first part, when there are no consumer in the South, this situation is also Pareto optimal (the North cannot be made better off without making the South worse off). With an increasing number of Southern consumers, the protection of the consumer surplus becomes marginally more attractive. For a sufficient low level of $s_{N}$, the Nash equilibrium is no longer Pareto optimal. The case of mutual cooperation (free entry, free entry) is preferred by both actors over mutual defection. The structure is however that of a Prisoner's Dilemma (PD), where unilateral defection is a dominant strategy. Given the strategic interaction it is necessary to have some agreements between the CAs such that cooperation can be sustained. It must be emphasized that this result is valid ceteris paribus. In fact - for a given $s_{N}$ - the incentives of the Southern CA to engage in negotiations over competition policy coordinations are dictated by the marginal cost savings of outsourcing: the more marginal cost saving are important, the smaller the incentives to find mutually cooperative solutions.

The main message of this paper is that if globalization leads to higher growth rates in consumption in the South than in the North - then the incentives to strike agreements on competition policy between "developed" and "developing" nations increase with globalization. However, such a cooperation may not be easily achieved if, for example, the interaction between Competition Agencies is of the Prisoner's Dilemma type. In this case, to successfully overcome the tendency of players to defect, strong agreements should be established - with provisions for detection of non-cooperative behavior and retaliation measures.

\section{Avenue for future research}

The theoretical model developed above predicts that globalization - and in particular the increase in the consumption share in the South - should ease international cooperation on competition policy issues. We would like to test this prediction empirically.

We should observe that - ceteris paribus - the probability of having international cooperation on competition policy is increasing, the lower the income difference and the higher the amount of intra-industry trade (as a proxy for trade in components) between the two countries are.

We are currently collecting data on country-pairs, specifying whether they have an agreement on competition policy issues. The resulting left-hand side variable is a dummy, so the empirical estimation will be a limited dependent variable model of the Probit-type. 


\section{References}

[1] Aggarwal, Vinod K. and Cédric Dupont (1999), "Goods, Games and Institutions," International Political Science Review 20(4), pp. 393-409.

[2] Antràs, Pol and Helanan Helpman (2004), "Global Sourcing," Journal of Political Economy, 112(3), pp. 552-580.

[3] Barros Pedro P. and Luis Cabral (1994), "Merger Policy in Open Economies," European Economic Review 38, pp. 1041-1055.

[4] Bernard, Andrew B., Stephen J. Redding and Peter K. Schott (2006), "Multi-Product Firms and Trade Liberalization," mimeo (November).

[5] Bhattacharjea, Aditya (2006), "The Case for a Multilateral Agreement on Competition Policy: A Developing Country Perspective," Journal of International Economic Law 9(2), pp. 293-323.

[6] Brander, James A. and Barbara J. Spencer (1981), "Tariffs and the Extraction of Foreign Monopoly Rents under Potential Entry," Canadian Journal of Economics 14(3), pp. 371-89.

[7] Brander, James A. and Barbara J. Spencer (1985), "Export subsidies and international market share rivalry," Journal of International Economics 18(1-2), pp. 83-100.

[8] Cabral Luis (2005), "An Equilibrium Approach to International Merger Policy," International Journal of Industrial Organization 23, pp. 739-751.

[9] Eaton, Jonathan and Gene M. Grossman (1986), "Optimal Trade and Industrial Policy under Oligopoly," Quarterly Journal of Economics 101(2), pp. 383-406.

[10] Evenett, Simon et al (2003), "Consumers, Multilateral Competition Policy and the WTO: Technical Report," Report for Consumers International.

[11] Grossman, Sanford J. and Oliver D. Hart (1986), "The Costs and Benefits of Ownership: A Theory of Vertical and Lateral Integration," Journal of Political Economy 94, pp. 691-719.

[12] Grossman, Gene M. and Elhanan Helpman (2002), "Integration Versus Outsourcing In Industry Equilibrium," Quarterly Journal of Economics, 117(1), pp. 85-120.

[13] Grossman, Gene M. and Elhanan Helpman (2005), "Outsourcing in a Global Economy," Review of Economic Studies 72(1): pp. 135-159.

[14] Helpman, Elhanan and Paul Krugman (1989), Trade Policy and Market Structure (Cambridge, MA: The MIT Press). 
[15] Hanson, Gordon H., Raymond J. Mataloni and Matthew J. Slaughter (2005), "Vertical Production Networks in Multinational Firms," Review of Economics and Statistics 87(4), pp. 664-678.

[16] Hart, Oliver D. (1995), Firms, Contracts and Financial Structure (Oxford: Oxford University Press).

[17] Head Keith and John Ries (1997), "International Mergers and Welfare under Decentralised Competition Policy," Canadian Journal of Economics 30(4b), pp. 1104-1123.

[18] Helpman, Elhanan, Marc J. Melitz and Stephen R. Yeaple (2004), "Export versus FDI with Heterogeneous Firms," American Economic Review 94, pp. 300-316.

[19] Hijzen, Alexander (2005), "A Bird's Eye View of International Outsourcing: Data, Measurement and Labour Demand," Economie Internationale 104, pp. $45-63$.

[20] Hart, Oliver and John Moore (1990), "Property Rights and the Nature of the Firm," Journal of Political Economy 98, pp. 1119-1158.

[21] Horn, Henrik and James Levinsohn (1997), "Merger Policies and Trade Liberalization," Economic Journal 111(470), pp. 244-276.

[22] Levenstein, Margaret C. and Valerie Y. Suslow. (2001). "Private International Cartels and Their Effect on Developing Countries," Background paper for the World Development Report 2001, World Bank.

[23] Melitz, Marc J. (2003), "The Impact of Trade on Intra-Industry Reallocations and Aggregate Industry Productivity," Econometrica 71, pp. 16951725 .

[24] Neary, J. Peter (2003), "The Road Less Travelled: Oligopoly and Competition Policy in General Equilibrium," in R. Arnott et al (eds), Economics for an Imperfect World: Essays in Honor of Joseph E. Stiglitz (Cambridge, MA: The MIT Press).

[25] Shy, Oz and Rune Stenbacka (2005), "Partial Outsourcing, monitoring costs, and market structure," Canadian Journal of Economics 38(4), pp. 1173-1190.

[26] Spencer, Barbara J. (2005), "International outsourcing and incomplete contracts," Canadian Journal of Economics 38(4), pp. 1107-1135.

[27] Yeats, Alexander J. (2001), "Just How Big is Global Production Sharing?," in Arndt, S. W. and H. Kierzkowski, Fragmentation: New Production Patterns in the World Economy (Oxford: Oxford University Press). 


\section{Appendix A1}

In Section 6 we provided a closed form solution to the strategic competition policy game, however under the simplifying assumption that fixed costs are zero. The simulations results shown in this Appendix suggest that fixed costs do have no qualitative impact on the solutions.

Adding fixed costs, the optimal solution under cooperation is to limit the number of firms in the market such that the marginal benefit of adding one more firm is equal to its fixed costs. Free entry is no longer optimal, but still the optimal outcome is close to the one corresponding with free entry.

For the non-cooperative outcome, the results are basically identical to the one without fixed costs. Fixed costs actually do also have a negative impact on the optimal number of firms in the South. Since the optimal number of firms is already very low (1 or 2 ) the only impact on result is that a monopoly becomes slightly more attractive. In a sense, the fact of having strategic actions completely dominates all other factors. Basically the results become mathematically much more involved but do not add any further intuition to the results without fixed costs. This is clear in Figure A1, where we compute cooperative and non-cooperative welfare levels for different levels of fixed costs (with parameters $\alpha=1000, \beta=0.5$ and $\left.s_{N}=0.5\right)$ :

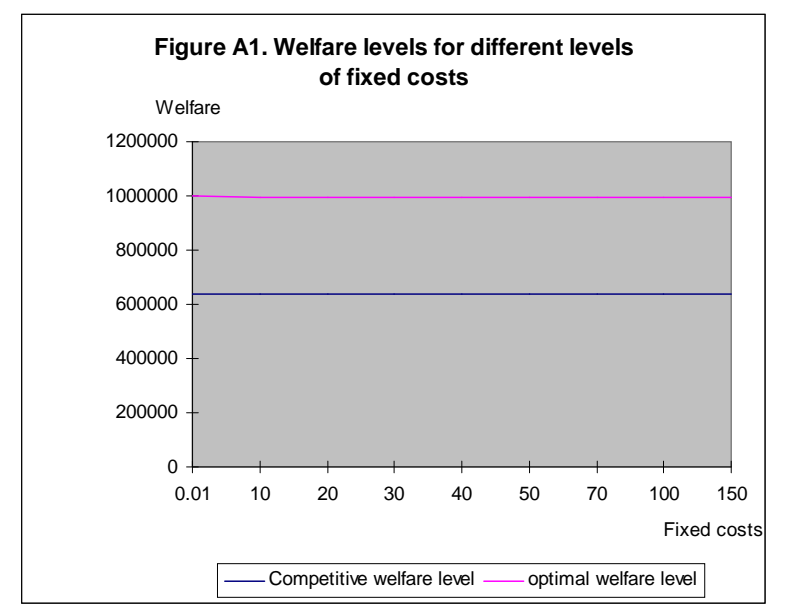

It is also interesting to see how results change with different distributions of consumers. Not surprisingly, the loss due to non-cooperation is decreasing in $s_{N}$. The more consumers are in the North, the smaller is the loss due to strategic competition policy. The intuition is the following. The South's objective is to shift part of the producer surplus from the final good producers in the North to the South. The reaction of the Northern CA is to reduce the number of final goods producers with the objective to shift Southern consumer surplus to the North. With increasing $s_{N}$ the Northern consumer surplus grows in importance, 
or the benefits of reducing the number of firms becomes smaller whereas the costs in terms of the domestic consumer surplus grows in importance. However the incentive of the Southern CA to react to different distributions of consumers is less, since it can only influence its own consumer surplus indirectly by lowering the price of intermediate goods.

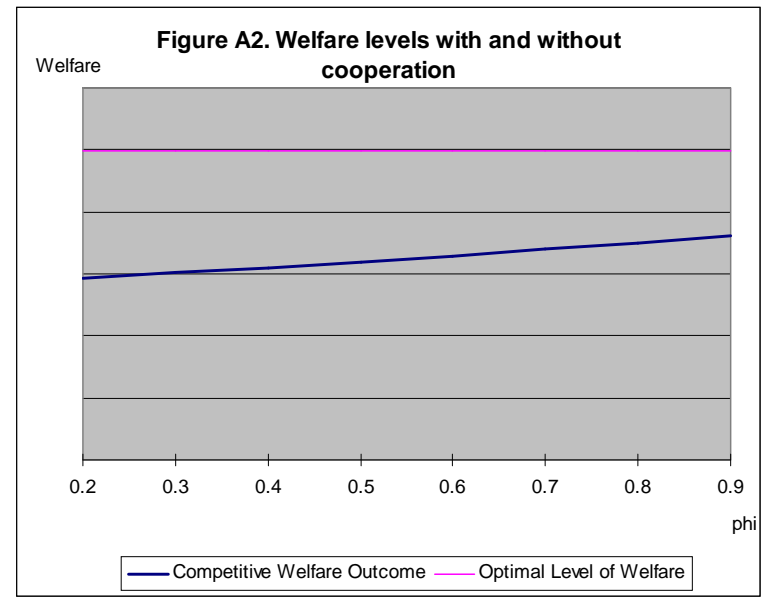

\section{Appendix A2}

Here we determine the unconstrained $\overline{s_{N}}$, defined as the maximum level of $s_{N}$ for which the interaction between the two CA's is of the Prisoner's Dilemma type. $\overline{s_{N}}$ corresponds to the situation in which the South is indifferent between the mutual cooperative outcome and mutual defection. We thus solve the following equality for $s_{N}$ :

$$
\frac{\alpha^{2}}{2\left(3-s_{N}\right)}=\frac{\left(1-s_{N}\right) \alpha^{2}}{4}
$$

The resulting quadratic equation has two roots, one of which is bigger then one. The unique acceptable solution is thus the one which is smaller than one, equal to $2-\sqrt{2}$. 